\title{
PENGARUH KOPI TERHADAP MEMORI JANGKA PENDEK PADA MAHASISWA PENDIDIKAN DOKTER UNIVERSITAS ABULYATAMA
}

\author{
Sefira Uhya ${ }^{1}$, Mursyida ${ }^{1}$, Iziddin Fadhil ${ }^{1}$ \\ ${ }^{1}$ Prodi Pendidikan Dokter, Fakultas Kedokteran, Universitas Abulyatama
}

\begin{abstract}
Effect Of Coffee On Short-term Memory In Student Of Abulyatama University Medical Education. Background coffee is one the most potent drinking related components in it, and it has an effect on the central nervous system so that it improves the performance of the box by stimulating the broadmann area on the prefrontal parts in the area 9,10,11, 12 which plays a role in storing information as referred to as memory the maximum can load thinking ability to store, retain, remember, judge, orient, perception, and pay attention to information received by individuals. Research Objective to find out the effect of consuming caffeine containing drinks on Abulyatama University Medical Education. Method this tipe of research is truly experimental. The study subjects consisted of 36 people aged 18-24 who were divided into 2 groups, namely 18 respondents drinking coffee and 18 respondents not drinking coffee. The data measured is the difference in short-term memory scores. The giving a cup of brewed coffee as much $20 \mathrm{gram}$ of coffee powder and 150 liters of water. Data analysis using unpaired " $t$ " test with $\alpha=0,05$. Result the average short term memory point after drinking coffee is 26.9444 greater than the average short memory points that do not drinks coffee that is equal to 23,0000 from the independent sample T-test statistical tests show $(2-$ tailed $)<0,05$ this proves there is a difference between the difference in short-term memory improvement between drinking coffee and not drinking coffee. Conclusion coffee improves short-term memory.
\end{abstract}

Keywords : Coffee, Short Term Memory

Abstrak: Pengaruh Kopi Terhadap Memori Jangka Pendek Pada Mahasiswa Pendidikan Dokter Universitas Abulyatama. Latar Belakang kopi merupakan salah satu minuman yang terkandung komponen kafein didalamnya serta memiliki efek pada sistem saraf pusat sehingga meningkatkan kinerja otak dengan menstimulasi area broadmann pada bagian prefrontalis pada daerah 9, 10, 11, 12 yang berperan dalam penyimpanan memori yaitu dapat memuat kemampuan berpikir untuk menyimpan, mempertahankan, mengingat, menilai, orientasi, persepsi dan memperhatikan informasi yang diterima oleh individu. Tujuan Penelian untuk mengetahui efek mengkonsumsi minuman yang mengandung kafein terhadap Mahasiswa Pendidikan Dokter Universitas Abulyatama. Metode tipe penelitian ini eksperimental sungguhan. Subjek penelitian terdiri atas 36 orang dengan usia 18-24 tahun yang dibagi menjadi 2 kelompok, yaitu 18 responden minum kopi dan 18 responden tidak minum kopi. data yang diukur adalah perbedaan skor memori jangka pendek. Pemberian secangkir kopi seduh dalam sekali minum sebanyak 20 gram bubuk kopi dan 150 liter air. Analisis data menggunakan uji " $t$ " tidak berpasangan dengan $\alpha=0,05$. Hasil rata-rata poin memori jangka pendek setelah minum kopi sebesar 26.9444 lebih besar dari rata-rata poin memori jangka pendek yang tidak minum kopi yaitu sebesar 23,0000 dari uji statistik independent sample T-test menunjukkan (2-tailed) < tailed. Hal ini membuktikan cenderung adanya perbedaan selisih peningkatan memori jangka pendek antar minum kopi dan tidak minum kopi. Kesimpulan kopi meningkatkan memori jangka pendek.

Kata Kunci : Kopi, Memori Jangka Pendek 


\section{PENDAHULUAN}

Saat ini peminat kopi semakin meningkat, terlihat dari banyaknya kalangan dewasa muda yang menghabiskan waktunya di warung kopi. Budaya mengkonsumsi kopi sudah sangat erat bagi masyarakat Aceh. Aceh merupakan salah satu kota penghasil kopi yang berkualitas baik, salah satunya kota Takengon (Gayo). Kopi tumbuh sangat subur didaerah Aceh sehingga Aceh sering dikenal dengan kota seribu warung kopi. Karakteristik aroma dan rasa kopi Aceh memiliki cita rasa khas sangat kompleks dan kekentalan yang kuat membuatnya sangat digemari oleh masyarakat aceh.

Komponen yang terkandung di dalam kopi adalah caffeine, kaffeol, trigonelline, amino acid, karbohidrat, alifatik acid, chlorogenat acid, lemak, mineral, komponen volatile, dan komponen karbonil (Ferdian, dkk 2018). Kafein memiliki efek pada sistem saraf pusat sehingga dapat meningkatkan kinerja otak dengan menstimulasi area broadmann pada bagian prefrontalis pada daerah $9,10,11,12$ yang berperan dalam penyimpanan informasi disebut sebagai memori (Intarti WD, dkk, 2014).

Kafein dapat meningkatkan mood, kemampuan kognisi, konsentrasi dan dapat mengurangi rasa kantuk (Triantara A.N, dkk, 2017). Pada penelitian ini menggunakan 20 gram bubuk jenis kopi Robusta yang mengandung kafein dalam 1 gram yaitu $(9,70 \mathrm{mg} / \mathrm{gram})$ 0,97\%.

Pengaruh kopi terhadap memori jangka pendek, yaitu memuat kemampuan berpikir untuk menyimpan, mempertahankan, mengingat, menilai, orientasi, persepsi dan memperhatikan informasi yang diterima oleh individu (Yusdiyanti, dkk, 2017).

Penilaian tingkat daya ingat dapat dinilai dengan MoCa-Ina (Montreal Cognitive Assessment) yaitu sebuah lembaran kuesioner memiliki sensifitas tinggi yang dikembangkan sebagai skrining cepat untuk menilai disfungsi kognitif ringan-sedang. MoCaIna memiliki 11 pertanyaan untuk menilai kemampuan kognitif meliputi atensi, bahasa, memori, dan fungsi visuospatial. Skor Moca-Ina 26-30 diinterpretasikan normal (tanpa gangguan kognitif) dan skor 25 cenderung mengindikasikan adanya gangguan kognitif (Rini SS, dkk, 2018). Mengetahui bahwa Aceh merupakan salah satu kota penghasil kopi yang berkualitas baik dan kopi juga memiliki efek yang sangat kuat terhadap daya ingat jangka pendek, maka peneliti tertarik untuk melakukan penelitian tentang pengaruh kopi terhadap memori jangka pendek.

\section{METODE}

Penelitian ini merupakan true eksperimental (post test only grup design) menggunakan pendekatan kuantitatif. Penelitian ini untuk melihat pengaruh kopi terhadap memori jangka pendek pada mahasiswa pendidikan dokter Universitas Abulyatama. Sampel penelitian yang diambil dengan metode accidental sampling pada seluruh mahasiswa pendidikan dokter Universitas Abulyatama yang telah sesuai dengan kriteria inklusi dan ekslusi sebagai berikut:

Kriteria inklusi dalam penelitian ini, yaitu:

a. Seluruh mahasiswa pendidikan dokter Universitas Abulyatama.

b. Mahasiswa pendidikan dokter yang berusia 17-24 tahun.

c. Mahasiswa yang cukup istirahat 68 jam/hari.

d. Mahasiswa yang 2 jam sesudah makan ringan atau 4 jam setelah makan berat.

Kriteria ekslusi dalam penelitian ini, yaitu:

a. Mahasiswa pendidikan dokter yang memiliki kebiasaan merokok dan mengkonsumsi alkohol.

b. Mahasiswa yang memiliki riwayat alergi terhadap kopi.

c. Mahasiswa yang mengkonsumsi obat-obatan.

d. Mahasiswa yang mengkonsumsi makanan atau minuman yang 
mengandung kafein dalam waktu 2 hari.

e. Mahasiswa yang memiliki riwayat gastritis.

Dalam penelitian ini peneliti melakukan wawancara kepada responden. Alat dan bahan yang digunakan adalah lembaran wawancara tes memori jangka pendek (Moca-Ina), stopwatch, alat tulis, bubuk jenis kopi robusta sebanyak 20 gram, air panas $150 \mathrm{ml}$, dan cangkir kopi. Subjek penelitian terdiri dari 36 orang yang bersedia menjadi responden penelitian dan menandatangani lembaran informed consent.

Pada penelitian ini, responden dibagi menjadi 2 kelompok, yaitu kelompok minum kopi dan kelompok tidak minum kopi. Responden penelitian ditempatkan di ruangan yang tenang agar dapat berkonsentrasi. Kemudian kelompok responden minum kopi diberi secangkir kopi yang sudah diseduh sebanyak 20 gram dalam sekali minum, setelah itu responden diberikan waktu istirahat dan rileks selama 5 menit sambil menunggu kafein dicerna dan diserap oleh tubuh untuk meningkatkan kinerja otak depan di mana jaringan memori berada. Sedangkan kelompok responden yang tidak minum kopi hanya dilakukan penilaian memori jangka pendek saja. Responden penelitian diminta untuk menyebutkan hari, tanggal, bulan, tahun dan tempat, kemudian menghubungkan huruf dan angka, menyalin gambar, melukis jam dinding, menyebutkan nama hewan yang ditunjukkan, menghitung, dan mengingat kata-kata yang diberikan pada lembaran tes Moca-Ina. Setelah selesai, peneliti menghitung jumlah kata yang dapat diingat responden dengan benar. Data yang diukur jumlah poin yang dapat diingat dan dilakukan dengan benar pada kelompok responden minum kopi dan tidak minum kopi.

\section{HASIL}

\section{Analisis Univariat}

a. Karakteristik Responden

Tabel 4.1 Distribusi Frekuensi Berdasarkan Karakteristik Responden

\begin{tabular}{lcc}
\hline \multicolumn{1}{c}{ Karakteristik } & Frekuensi (n) & Persentase (\%) \\
\hline Jenis Kelamin & & 30 \\
\hline Laki-Laki & 11 & 70 \\
\hline Perempuan & 25 & 8 \\
\hline Usia & 3 & 25 \\
\hline 18 tahun & 9 & 36 \\
\hline 19 tahun & 13 & 20 \\
\hline 20 tahun & 7 & 8 \\
\hline 21 tahun & 3 & 3 \\
\hline 23 tahun & 1 & $\mathbf{1 0 0}$ \\
\hline 24 tahun & $\mathbf{3 6}$ & \\
\hline Total & &
\end{tabular}


Berdasarkan tabel di atas kategori umur responden yang menunjukkan bahwa kategori jenis terbanyak adalah 20 tahun (36\%).

kelamin responden yang terbanyak

adalah perempuan 25 orang $(70 \%)$ dan

b. Responden Minum Kopi Dan tidak Minum Kopi

Tabel 4.2 Distribusi Frekuensi Minum Kopi Dan tidak Minum Kopi

\begin{tabular}{ccc}
\hline Kopi & Frekuensi & \% \\
\hline Ya & 18 & 50 \\
\hline Tidak & 18 & 50 \\
\hline Total & $\mathbf{3 6}$ & $\mathbf{1 0 0}$ \\
\hline
\end{tabular}

Berdasarkan tabel di atas diketahui bahwa responden minum kopi sebanyak

18 responden (50\%) dan tidak minum kopi sebanyak 18 responden (50\%).

c. Poin Memori Jangka Pendek

Tabel 4.3 Distribusi Frekuensi Poin Memori Jangka Pendek

\begin{tabular}{ccc}
\hline Memori Jangka Pendek & Frekuensi & \% \\
\hline $26-30$ Poin & 18 & 50 \\
\hline$<25$ Poin & 18 & 50 \\
\hline Total & $\mathbf{3 6}$ & $\mathbf{1 0 0}$
\end{tabular}

Berdasarkan tabel di atas sebanyak 18 responden $(50 \%)$ dan $<25$ diketahui bahwa jumlah poin memori poin sebanyak 18 responden (50\%).

jangka pendek 26-30 poin yaitu

\section{Analisis Bivariat}

a. Rata-Rata Skor Hasil Tes Memori Jangka Pendek

Tabel 4.4 Rata-Rata Skor Hasil Tes Memori Jangka Pendek

\begin{tabular}{lccccc}
\hline Hasil & Kelompok & $\mathbf{N}$ & Mean & $\begin{array}{c}\text { Std. } \\
\text { Deviation }\end{array}$ & Std. Error Mean \\
\hline Minum Kopi & 18 & 26.9444 & 1.16175 & .27383 \\
\hline Tidak Minum Kopi & 18 & 23.0000 & 1.137199 & .32338 \\
\hline
\end{tabular}

Berdasarkan tabel di atas bahwa rata skor sebelum minum kopi sebesar rata-rata skor setelah minum kopi $26.9444(\mathrm{SD}=1.6175)$ sedangkan rata-

$23.0000(\mathrm{SD}=1.37199)$.

b. Data Pengaruh Kopi terhadap memori jangka Pendek

Tabel 4.5 Hasil Pengolahan Data Poin pengaruh kopi terhadap memori jangka pendek

\begin{tabular}{lccccrrr}
\hline & $\mathrm{F}$ & Sig. & $\mathrm{t}$ & $\mathrm{df}$ & $\begin{array}{c}\text { Sig (2- } \\
\text { tailed) }\end{array}$ & $\begin{array}{c}\text { Mean } \\
\text { Difference }\end{array}$ & $\begin{array}{c}\text { Std. Error } \\
\text { Difference }\end{array}$ \\
\hline $\begin{array}{l}\text { Poin Minum } \\
\text { Kopi }\end{array}$ & .510 & .480 & 9.309 & 34 & .000 & 3.94444 & .42374 \\
\hline $\begin{array}{l}\text { Poin Tidak } \\
\text { Minum Kopi }\end{array}$ & & & 9.309 & 33.101 & .000 & 3.94444 & .42374 \\
\hline
\end{tabular}


Berdasarkan hasil tabel di atas cenderung menunjukkan adanya pengaruh kopi yang berbanding lurus terhadap memori jangka pendek dapat dilihat dari jumlah signifikan (2-tailed)

\section{PEMBAHASAN}

Berdasarkan hasil penelitian di atas cenderung menunjukkan adanya pengaruh yang berbanding lurus terhadap memori jangka pendek. Ada pula mekanisme kerja kafein pada sistem saraf pusat yaitu sebagai stimulan yang dapat meningkatkan daya ingat dengan cara menghambat salah satu pusat yang membuat tubuh merasa lelah dan mengantuk yaitu senyawa adenosine yang berasal dari pemecahan ATP berperan dalam metabolisme lipid dan kolestrol (Koupenova, dkk, 2014).

Diotak terdapat neuron yang memiliki reseptor khusus untuk menyerap adenosine. Saat seseorang beraktivitas, adenosine secara bertahap akan terkumpul dan mengikat pada reseptor otak sehingga menyebabkan kinerja otak melambat dan memicu terjadinya penurunan konsentrasi, fungsi kognitif dan juga mood. Semakin banyak adenosine yang terkumpul diotak maka semakin pula membuat otak merasa lelah dan mengantuk. Apabila seseorang tetap memaksa untuk beraktivitas maka akan semakin pula merasa lelah dan mengantuk yang lebih berat sehingga mendorong keinginan untuk tidur, sebaliknya ketika beristirahat atau tidur yang cukup maka jumlah ikatan adenosine pada reseptor otak cenderung menurun secara bertahap sehingga merangsang tubuh untuk bangun dan siap untuk beraktivitas kembali. Oleh karena itu, kopi sangat membantu dalam peningkatan konsentrasi, fungsi kognitif dan juga mood seseorang. Jadi, setelah mengkonsumsi kopi dalam waktu 15120 menit senyawa kafein yang terkandung didalam kopi akan di distribusikan keseluruh tubuh oleh aliran darah dengan cara menghambat kinerja adenosine untuk mengikat reseptor yang ada diotak sehingga rasa lelah dan mengantuk cenderung adalah 0,000 atau $(<0,05)$ uji statistik cenderung menunjukkan adanya perbedaan yang lebih baik antara perlakuan minum kopi dari pada perlakuan tidak minum kopi.

tergantikan dan membuat tubuh menjadi lebih bugar juga siap untuk menerima informasi yang baik sebagai penyimpanan memori (Irma Z, dkk, 2018).

Penelitian yang dilakukan oleh Heatherley et al. yang menyatakan bahwa konsumsi kafein dengan dosis tunggal dapat meningkatkan kewaspadaan, perhatian dan memori (Rogers PJ, dkk, 2013). Beberapa studi juga melaporkan menurut Snel \& Lorist dalam Alifiyah Roro Maghfirah bahwa kafein bermanfaat untuk memulihkan tingkat kewaspadaan atau tingkat terjaga seseorang dan mengimbangi kemampuan kognitif (Magfiroh AR, dkk, 2019).

Hasil penelitian ini didukung oleh penelitian yang dilakukan Liviera Grace Surya Chandra tahun 2012 yang melakukan penelitian dengan rancangan pre-test dan post-test terhadap 40 orang dengan jenis kelamin perempuan usia 19-23 tahun. Hasil rata-rata skor memori jangka pendek setelah minum kopi sebesar 44.4 lebih besar dari pada rata rata skor memori jangka pendek sebelum minum kopi yaitu sebesar 35.4 ( $p<0.01)$. Terdapat perbedaan selisih peningkatan memori jangka pendek yang sangat signifikan antara sesudah dan sebelum minum kopi (Chandra LGS, dkk, 2012).

Penelitian ini juga sejalan dari Nikko tahun 2015 melakukan penelitian terhadap 30 laki-laki dewasa berusia 18-25 tahun. Penelitian dilakukan dengan rancangan pre-test dan posttest. Hasil penelitian yang didapat adalah jumlah kata yang diingat sesudah meminum kopi robusta lebih tinggi, yaitu 44,73 dibandingkan dengan sebelum diberi minum kopi robusta, yaitu 34,07 dengan perbedaan yang sangat signifikan $(p<0,01)$. Kopi robusta dapat meningkatkan memori jangka pendek (Nikko, dkk, 2015). 


\section{KESIMPULAN}

Dari hasil penelitian dapat disimpulkan bahwa pada perlakuan minum kopi cenderung berbanding lurus dengan memori jangka pendek. Hal ini menunjukkan bahwa perlakuan minum kopi lebih baik dibandingkan perlakuan tidak minum kopi yang dapat dilihat dari signifikan (2-tailed) adalah 0,000 atau $(<0,05)$ sehingga membuktikan bahwa kandungan kafein di dalam kopi memiliki pengaruh yang bermakna terhadap memori jangka pendek.

\section{SARAN}

Dari hasil penelitian yang dilakukan penelitian saran-saran yang dapat dikemukan, yaitu bagi penelitian selanjutnya diharapkan jumlah sampel

\section{DAFTAR PUSTAKA}

Chandra LGS. (2012). Pengaruh Kopi (Coffea arabica) Terhadap Memori Jangka Pendek. [Tesis]. Bandung: Universitas Kristen Maranatha.

Ferdinand C, Olivia S. (2018). Hubungan kafein terhadap daya ingat jangka pendek pada mahasiswa angkatan 2012 Fakultas Kedokteran Universitas Tarumanagara. Tarumanagara Medical Journal, 1(1): 41-47.

Intarti WD, Savitri NPH. (2014). Pengaruh Tinggi Badan Terhadap Kecerdasan Kognitif Murid TK A AlMuhajidin Cilacap, Jurnal Ilmiah Kebidanan 5(4): 63-76.

Irma Z, Dewi S. (2018). Pengaruh suhu dan waktu ekstraksi terhadap kafein dalam kopi. Jurnal Lantanida 6(2): 1-12.

Koupenova M, Ravid K. (2014). Adenosine, Adenosine Receptor Their Role Glucose Homeostatis Lipid Metabolism, J Cell Physiol: 617-638.

Maghfiroh AR. (2019). Pengaruh Kafein Kopi Pada Perhatian: Penelitian Eksperimen di Pondok Pesantren As-Salafiyyah. Jurnal UIN Sunan penelitian lebih besar agar dapat melihat perbedaan yang lebih bermakna berkaitan dengan pengaruh kopi terhadap memori jangka pendek, juga diharapkan dapat melakukan metode penelitian yang berbeda dengan mengetahui bahwa kopi banyak mengandung komponen - komponen yang bermanfaat bagi tubuh dan melihat banyaknya penggemar kopi didaerah Aceh, seharusnya penelitian ini dapat memberikan publikasi dan sosialisasi kepada masyarakat mengenai manfaat kopi yang bertujuan untuk meningkatkan pengetahuan terhadap dosis kopi yang dikonsumsi setiap harinya agar masyarakat lebih mengetahui bagaimana mengkonsumsi kopi yang baik dan bermanfaat bagi tubuh khususnya tingkat daya ingat.

Kalijaga Yogyakarta, pp. 56-61.

Nikko. (2015). Pengaruh Kopi Robusta Terhadap Memori Jangka Pendek Pada Laki-Laki Dewasa Muda. Abstrak Undergraduate Thesis. Universitas Kristen Meranatha 73: 1-8.

Rini SS, Kuswardhani T, Aryana S. (2018). Faktor - Faktor Yang Berhubungan Dengan Gangguan Kognitif Pada Lansia Di Panti Sosial Tresna Werdha Wana Seraya Denpasar. Jurnal Penyakit Dalam Udayana 2(2): 32-37.

Rogers PJ, Heatherley SV, Mullings EL, Smith JE. (2013). Faster but not Smarter: Effects of Caffeine and Caffeine Withdrawal on Alertness and Performance. Psychopharmacology (Berl) 226(2): 229-40.

Triantara AN, Wijayanti HS. (2017). Perbedaan Kualitas Tidur Setelah Mengkonsumsi Berbagai Jenis Minuman Kopi Pada Usia Dewasa, Journal of nutrition college 184(4681): 156.

Yusdiyanti D, Hardian H, Sumekar, TA. (2017). Pengaruh Brain Training 
Terhadap Memori Diukur Dengan

Scenery Picture Memory Test.

Jurnal Kedokteran Diponegoro,

6(2), 460-469. 